
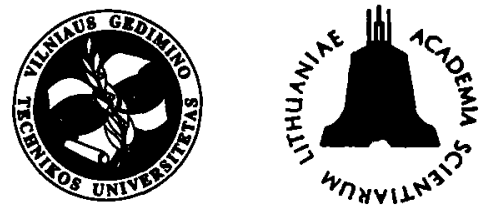

JOURNAL OF CIVIL ENGINEERING AND MANAGEMENT

http:/www.vtu.lt/english/editions

2003. Vol IX, No 3, 203-207

\title{
EVALUATION OF SORPTION MOISTENING IN RESEARCH OF MOISTURE- CAUSED DEFORMATIONS OF BUILDING MATERIALS
}

\author{
Rũta Miniotaitè', Vytautas Stankevičius ${ }^{2}$ \\ Laboratory of Building Thermal Physics, Institute of Architecture and Construction, \\ Tunelio 60, LT-3035 Kaunas, Lithuania \\ ${ }^{1}$ E-mail: rutaminiot@centras.lt,2E-mail: silfiz@asi.lt
}

Received 04 Sept 2002; accepted 12 Febr 2003

\begin{abstract}
Investigation methods described in literature and standards do not evaluate the influence of sorption moisture upon moisture-caused deformations of building materials. Therefore, the usual deformations measuring methods had to be amended by measuring moisture deformations in various models and by setting sorption moisture. The improved methods was applied for solving the tasks of durability of articles.

The basic point of the developed methods intended for investigating the moisture-caused deformations is investigation of the groups of specimens by measuring deformations in the environment of fixed sorption moisture using four models. According to the methods described in this article, the dependence of deformations $\left(\mathrm{e}_{u}\right)$ of various construction materials (concrete, porous concrete, sand-lime and ceramic bricks, cement-lime plasters) upon moisture and changes therein was investigated: $\mathrm{e}_{u}=f(u)$. Analysing the materials with different capillary structures enables us to provide - in a very concise form - some references concerning value and nature of deformations.

Linear moisture-caused deformations of basic construction materials (concrete, sand-lime and ceramic bricks, cementlime plasters, porous concrete) vary within the limits of $0,33-0,77 \mathrm{~mm} / \mathrm{m}$. In case of articles containing organic fillings they can reach up to $6 \mathrm{~mm} / \mathrm{m}$.

When the material is of a fine capillary structure the highest relative moisture elongation $K$ of a material is observed in the environment of vapour area. Relative moisture elongation of the tested materials with the outset of intense capillary condensation varies from $0,05 \mathrm{~mm} /(\mathrm{m} \times \%)$ to $0,51 \mathrm{~mm} /(\mathrm{m} \times \%)$.
\end{abstract}

Keywords: building materials, moisture-caused deformation, water vapour sorption, improved methods.

\section{Introduction}

In case of porous materials, no equilibrium of molecular forces exists between the particles on the surface of the pores, and surface tension occurs in the framework of a solid body [1-13]. With moistening a capillary-porous body and under the action of capillary forces the body volume increases due to the increase of dimensions of material polycrystalline structure.

In case of crystals, moisture adsorption reduces the forces of molecular links (bonds) between the layers and increases the distance between them.

With increased time of exposure to the environment, materials begin to degrade, which can result in either a catastrophic failure or gradual drift out of tolerance of a critical performance property of the material. The durability problem is concerned with the deterioration of the material to such a level that an undesirable or unsafe condition for the material or component is attained $[3,10]$.
Fluid pressure variations in porous materials not only involve mass transfer, but also deformations of the porous material. These deformations, when restrained, can lead to damage and severe cracking [3, 4].

With elimination of moisture from the pores, molecular bond increases and initiates shrinkage of materials. It is supposed that in the environment of super-sorption moisture, the action of capillary forces remains constant due to saturated vapour pressure in the pores; with the increase of moisture up to the maximum water absorption, the material does not undergo further deformation [5-6, 14-16].

Investigation methods intended for research on moisture-caused deformations of moistened and soaked specimen are described in literature and standards. They are not related to variable processes of sorption and desorption [7-9, 17-18]. The influence of sorption moistening values upon moisture-caused deformations of materials are not determined yet. Therefore the usual deformations measuring methods had to be amended by measuring 
moisture deformations in various models and by setting sorption moisture $[8,9]$. The improved methods was applied for solving the tasks of durability of articles.

\section{Investigations of moisture-caused deformations}

According to the methods described in this article, the dependence of deformations $\left(e_{u}\right)$ of structural materials (concrete, sand-lime and ceramic bricks, cementlime plasters, porous concrete) upon moisture and changes therein was investigated: $\mathrm{e}_{u}=f(u)$. Investigation methods were improved and developed on the ground of a cement-wood chipboard example; afterwards they were employed for investigating other materials. The basic point of the developed methods intended for the analysis of moisture-caused deformations is investigation of the specimen groups by measuring deformations in the environment of fixed sorption moisture using four models [3, 8-9]:

Model $I$ - specimens were soaked in water at temperature $(18-25)^{\circ} \mathrm{C}$ till absolute absorption. Afterwards, the specimens were dried under room conditions at the air temperature $(18 \pm 2)^{\circ} \mathrm{C}$ and $\mathrm{RH}$ (relative humidity) $\mathrm{f}$ $=(45-50) \%$ up to equilibrium state. The above state reached, the specimens were dried at an ambient temperature $(105 \pm 2)^{\circ} \mathrm{C}$ until a dry state was achieved;

Model $I I$ - specimens were soaked at $60^{\circ} \mathrm{C}$ in polyethylene bags. The bags contained such volume of water which was almost totally absorbed by the specimen. Then the specimens were dried at the same temperature in empty (no water) polyethylene bags so that more identical conditions were created for distribution of moisture;

Model III - specimens were tested under the conditions identical to those of Model $I$, however, they were moistened gradually in the course of entire sorption process up to complete absorption, while soaked in water;

Model $I V$ - specimens were tested under the conditions identical to those of Model $I I$, however, they were moistened gradually according to sorption process and then up to the total absorption.

For evaluation of the deformations, the length of a dry specimen was taken as the basic length. The length of each specimen were measured at $0,0001 \mathrm{~mm}$; the mass accuracy of $0,01 \mathrm{~g}$. Moisture-caused deformations of structural materials were measured simultaneously with gradual moistening and then gradually dried following the achievement of maximum absorption.

Moisture-caused deformations of specimens were valued by two parameters [8-9]:

1. Linear deformations of a material $\varepsilon_{u},[\mathrm{~mm} / \mathrm{m}]$ :

$$
\begin{gathered}
\Delta l=l_{u}-l_{b}, \\
\varepsilon_{u}=\frac{\Delta}{l_{b}},
\end{gathered}
$$

where $l_{b}$ - basic length of a specimen, $\mathrm{mm} ; l_{u}$ - measured length of a damp specimen, $\mathrm{mm}$.
2. Relative moisture elongation of material $K$, $[\mathrm{mm} /(\mathrm{m} \times \%)]$ :

$$
K=\frac{\varepsilon_{u}}{\Delta u}
$$

where $\Delta u=\left(u_{2}-u_{1}\right), \%$ - accrual of material moisture (essentially, the sorption moisture), $\%$, within the interval from moisture $u_{1}$ to moisture $u_{2}$.

$K$ is a significant comparative property of the material indicating relative change of material length with moisture change of one percent.

The process of moisture transfer is an inert one and therefore the experiment of investigation of moisturecaused deformation is time-consuming; precision of measurements depends on escaping from the influence of accidental effects. Measuring practices indicated that negligible accidental deviations resulted in distortion of the result and required repetition of the experiment already well-advanced.

According to the methods described in this article, the dependence of deformations $\left(e_{u}\right)$ of various structural materials upon moisture content $(u)$ and changes therein was investigated: $e_{u}=f(u)$. Investigation methods were improved and developed on the ground of a cement-wood chipboard example; afterwards they were employed for investigation of other materials [8-9].

\section{Results}

In Fig 1 the field of isolines of deformations was divided into three areas: in case of the lst area, the moisture of the specimen corresponds to vapour-state sorption moisture of the material, including adsorption moisture (1-2); in case of the 2 nd area (3), moisture of the specimen complies with that of an intensive capillary condensation; and in case of the 3rd area (4) the specimen was moistened by free moisture. In Fig 2, the areas of moisture states are marked " $1-2$ ", " 3 " \& " 4 ".

Analysing the moisture-caused deformations of materials with different capillary structures enables us to provide - in a very concise form - some references concerning volume and nature of deformations.

Relative moisture elongation of materials of the articles possessing fine capillary and homogenous structure, eg deformations of a sand-lime brick, grew abruptly and rapidly in the area of sorption moisture (Fig 2) $[8-9,18-20]$. It was determined that when the articles were dried in the environment of temperature $105^{\circ} \mathrm{C}$, about $0,5 \%$ of non-eliminated moisture remained therein, and residual deformations proportional to the quantity of non-eliminated moisture were observed.

Weakly-bonded structures such as specimens of lime mortar undergo deformations in quite a different way (Fig 3) $[8-9,16,20,21]$. When soaked in water, they swell rapidly. When water temperature reaches $60^{\circ} \mathrm{C}$ and water viscosity decreases (according to Model $I I$ ), the plaster gets water-saturated in several minutes. Moisture- 
caused deformations do not increase with further moistening. Residual deformations of the specimens correspond to the value reached during the intense swelling.

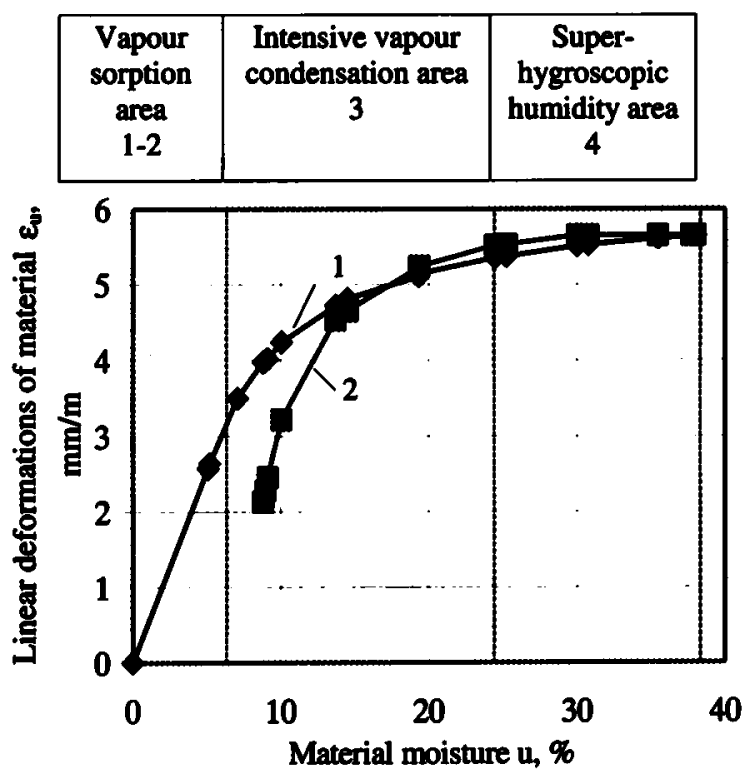

Fig 1. Linear deformations caused by moistening (1) and drying (2) of cement-wood chipboards according to Model III

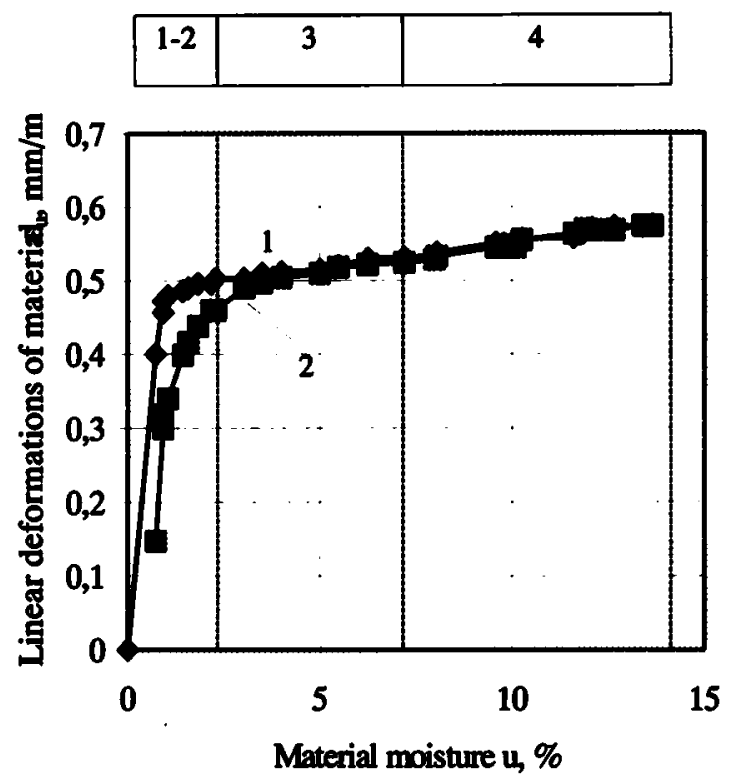

Fig 2. Linear deformations caused by moistening (1) and drying (2) and sand-lime brick according to Model III

Intensive swelling was also observed while testing lime cement according to Models I (Fig 4) \& II (soaking in water). In the above case, high hysteresis of isotherms drying and moistening as well as a characteristic shape of moistening isotherm were observed. Within the interval $u=(1,5-4) \%$ (intense capillary condensation area), relative moisture elongation of the lime cement $K$ $O$ (the material stops to extend). Afterwards the elon- gation slowly grows, later more rapidly up to the limit characteristic of the lime cement. The above can be explained by the presence of two materials (lime and cement) with different abilities of water absorption. At the beginning the lime absolutely disturbs cement to adsorb water vapour $(u<4 \%)$. During saturation the lime less and less disturb $b_{1}$ cement to absorb water. Relative moisture elongation at the end of saturation reaches value $K=0,12 \mathrm{~mm} /(\mathrm{m} \times \%)(u » 15 \%)$. During the drying process of the plaster the recurrence of volume is very slow, the hysteresis is high $[12,16,18,22]$.

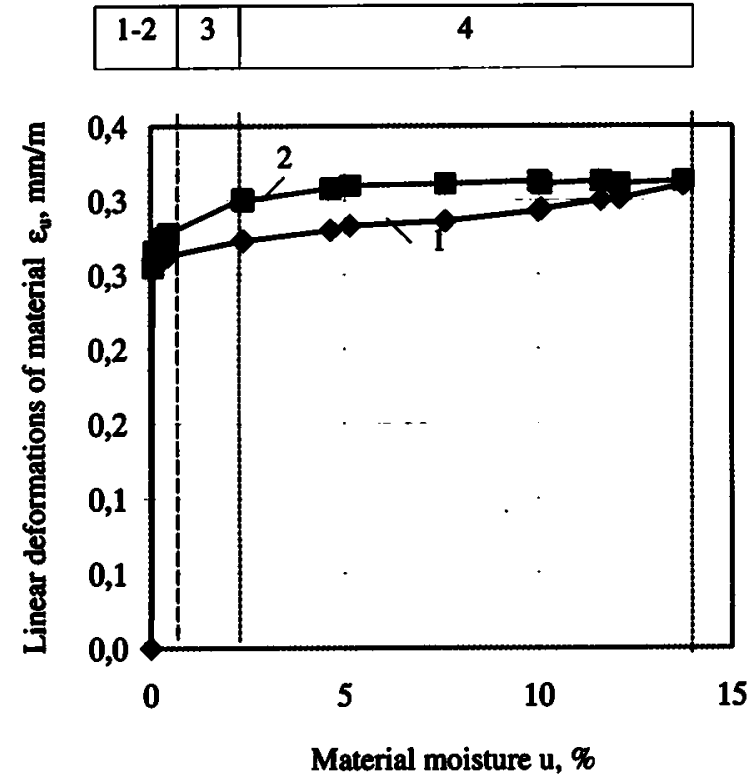

Fig 3. Linear deformations caused by moistening (1) and drying (2) lime plaster (1:3) according to Model II
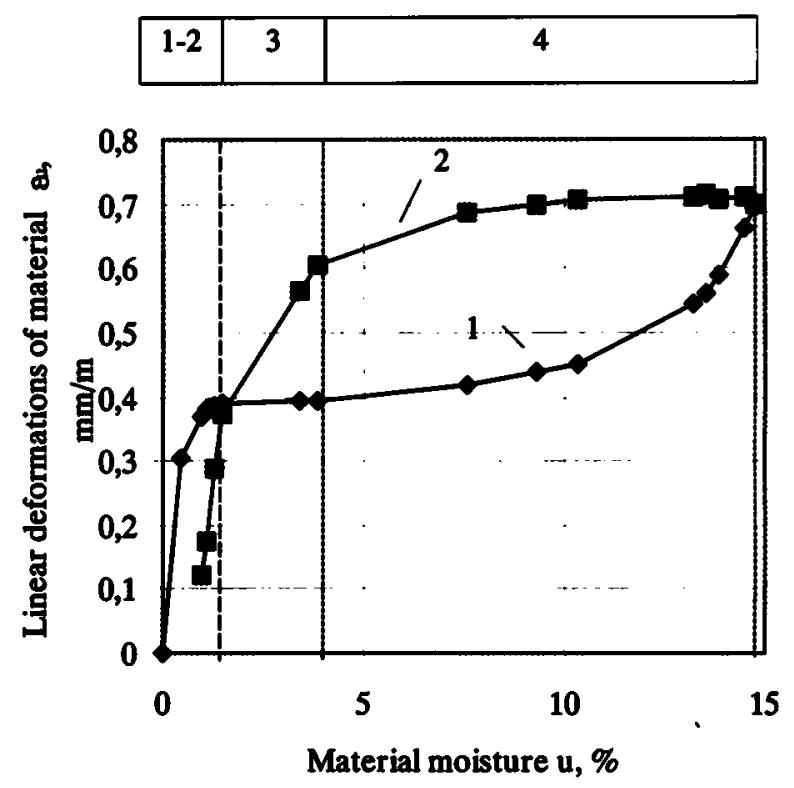

Fig 4. Linear deformations caused by moistening (1) and drying (2) cement-lime plaster $(1: 1,2: 6,8)$ according to Model $I$ 
When heavy concrete is moistened at $20^{\circ} \mathrm{C}$ temperature environment according to Model $I$ (Fig 5), moistening rate is practically constant until a complete humidification in the area of capillary condensation $[8,22]$.

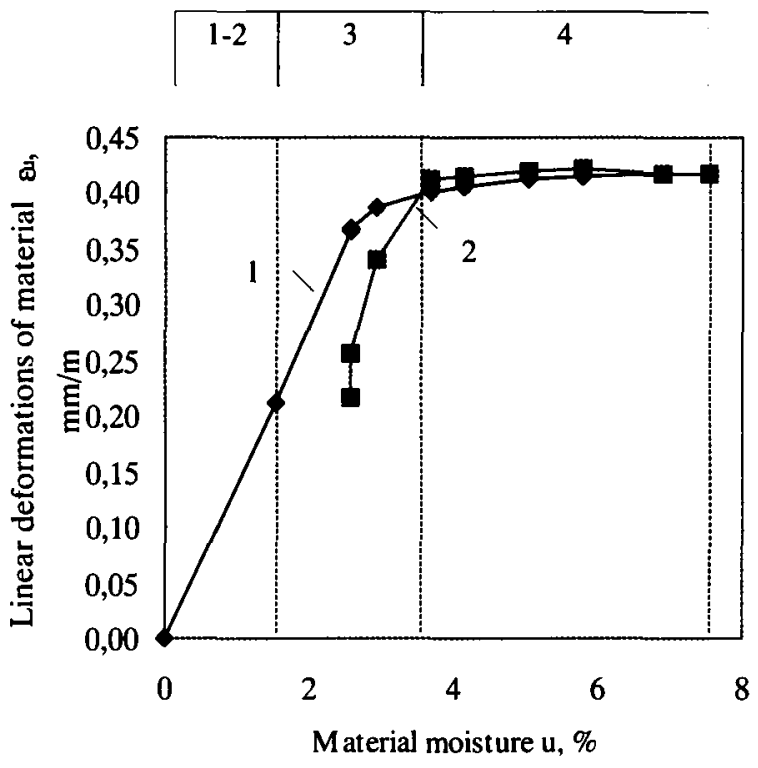

Fig 5. Linear deformations caused by moistening (1) and drying (2) concrete according to Model I

Samples of porous concrete, tested according to Models $I$ (Fig 6) \& II (temperature $\theta, 20$ and $60^{\circ} \mathrm{C}$ respectively; moistened by direct contact with water) up to the moistening corresponding to the $(1-2)$ sorption area, were also getting intensively moistened in proportion to ambient moisture accrual. In this case, relative moisture elongation of material $K=(0,46-0,57) \mathrm{mm} /(\mathrm{m} \times \%)$, at humidity level up to $u \leq(3-4) \%$ depends on the ratio of rapidly water-filled open pores and narrow water-sucking capillaries linking the pores. The more open the porosity is, the bigger is the relative moisture elongation $K$ of the material and, consequently, more rapidly linear deformations develop up to the limit of their moisturecaused deformation. Isotherms of drying practically correspond to moistening isotherms up to polymolecular (filmy) level of moisture; once the level is reached, they practically break - residual deformations and residual moisture are already fixed in the gas concrete. The influence of temperature is low and fits within the limits of testing accuracy.

Investigation results indicated that functional dependence of material deformations upon moisture might be put into a certain variation curve close to that of parabola; different are function variation parameters which depend on the nature of the material, microstructure and molecular link of moisture with the framework of the material.

However, variation parameters of the function $\varepsilon_{u}=f(u)$ are different for each material and should be calculated individually.

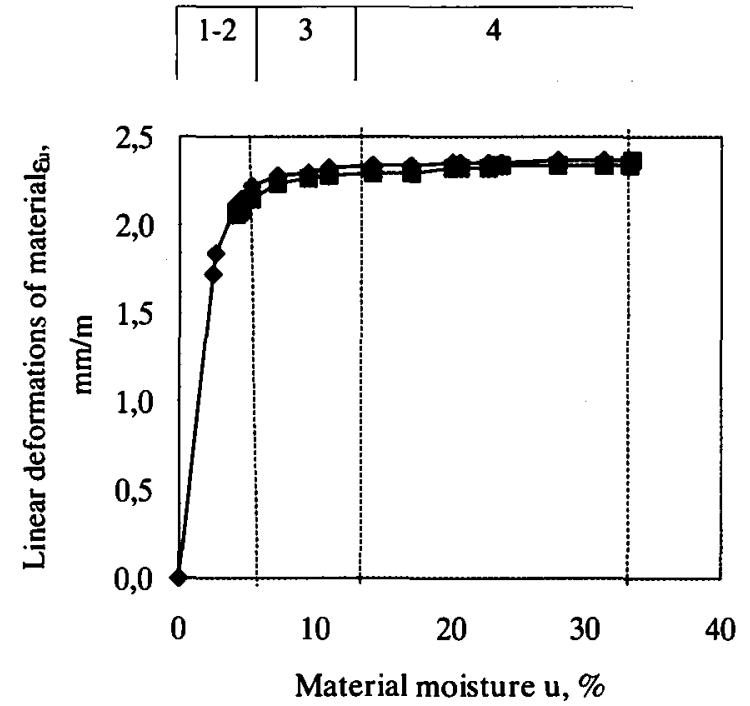

Fig 6. Linear deformations caused by moistening (1) and drying (2) porous concrete according to Model $I$

\section{Conclusions}

1. All tested structural materials usually get deformed in the area of sorption moisture before reaching the state of intense capillary condensation. Moisturecaused deformations finally settle in the state of intense capillary condensation.

2. Linear moisture-caused deformations of basic construction materials (concrete, sand-lime and ceramic bricks, cement-lime plasters, porous concrete) vary within the limits of $0,33-0,77 \mathrm{~mm} / \mathrm{m}$. In case of articles containing organic fillings linear moisture-caused deformations can reach up to $6 \mathrm{~mm} / \mathrm{m}$.

3. In case of a material containing plastifying additives, including lime, residual moisture and residual deformations are observed.

4. The highest relative moisture elongation $K$ of a material is observed in the environment of vapour area; it is directly proportional to moisture growth at a large relative surface of capillaries and pores per volume unit, ie when the material is of a fine capillary structure. Relative moisture elongation $K$ of the tested materials with the outset of intense capillary condensation varies from $0,05 \mathrm{~mm} /(\mathrm{m} \times \%)$ to $0,51 \mathrm{~mm} /(\mathrm{m} \times \%)$.

\section{References}

1. Store $\mathbf{M}$. Water vapour permeability and sorption curves of painted substrates materials. In: Proc. of symposium of building physics in the Nordic countries, Finland, 1996, p. 691-698.

2. Hansen K. K. Equipment for and results of water vapour transmission tests using cup methods. In: Proc. of ICHMT symp. heat and mass transfer in building materials and structures, Dubrovnik, Yugoslavia, 1989, p. 127-132.

3. Hansen K. K.; Hansen E. J. Unfired clay bricks - moisture properties and compressive strength. In: Proc. of $6^{\text {th }}$ 
symposium on building physics in the Nordic countries, Trondheim, Norway, 1990, p. 453-460.

4. Miniotaitė R.; Stankevičius V. Sorption-desorption of building materials. In: Proc. of healthy buildings' 1994 conference, Budapest, Hungary, 1994, p. 141-145.

5. Miniotaite $R$. The durability of finishing layer external surface of building walls (Pastatu sienı̨ dažytu paviršiu ilgaamžiškumas). Monograph. Kaunas: Technologija, 2001. 175 p. (in Lithuanian).

6. Carmeliet J. and Roels S. Determination of the isothermal moisture transport properties of porous building materials. $J$. of Thermal Envelope \& Building Science, Vol 24, 2001, p. 183-210.

7. Bomberg M.; Haghighat F.; Grunewald J.; Plagge R. Capillary transition point as a material characteristic for HAM models. In: Proc. of $4^{\text {th }}$ int. conf. on IAQ, ventilation and energy conservation in buildings, Vol 1, 2001, p. $755-762$.

8. Freitas V. P.; Abrantes V.; Crausse P. Moisture migration in building walls - analysis of the interface phenomena. Building and Environment, Vol 31, No 2, 1996, p. 99-108.

9. Cerny R.; Drchalova J.; Hoskova S.; Toman J. Inverse problems of moisture transport in porous materials. In: Proc. of second ECCOMAS conf. on numerical methods in engineering, 1996, p. 664-670.

10. Hedenblad G. Moisture permeability of some porous materials. In: Proc. of $3^{\text {rd }}$ symposium on building physics in the Nordic countries, Copenhagen, Vol 2, 1993, (Saxhof, B., editor), p. 697-702.

11. EN ISO 12571:2000. Building materials. Determination of hygroscopic sorption properties.

12. prEN ISO 15148. Building materials. Determination of water absorption coefficient by partial immersion, CEN/ TC 89 WG10 N 189 30-09-1997.

13. Hansen K. K.; Baroghel V. B.; Quenard D. and Künzel H. Water vapour absorption isotherms for porous building materials. In: Proc. of international symposium on moisture problems in building walls. Portugal, 1995 (Abrantes V., editor), p. $248-257$
14. EN ISO 12572:2001. Building materials. Hydrothermal performance of building materials and products. Determination of water vapour transmission properties.

15. Hale D. K. The physical properties of composite materials (review). Journ. of Material Science, Vol 11, 1976, p. 2105-2141.

16. Lentinen, T. Capillary moisture transfer in combined porous building materials. In: Proc. of symposium on building physics in the Nordic countries, Finland, 1996, p. 483490.

17. Carmeliet J. and Roels S. Moisture transfer and durability of open porous media. In: Proc. of 4th symposium on building physics in the Nordic countries, Finland, Vol 2, 1996, p. 587-594.

18. Miniotaitè R. Compatibility of finishing layer and external surface of buildings walls from the standpoint of durability (Pastatu sienı išorinio apdailos sluoksnio ir pagrindo suderinamumas ilgaamžiškumo požiūriu). Doctoral dissertation, Kaunas, Lithuania, 1999. 180 p. (in Lithuanian).

19. Miniotaite R. Determination method for weather durability of finish layers in external walls of buildings (Pastaty išoriniy sieny apdailos sluoksniy atsparumo klimatui nustatymo metodika). In: Proc. of conference on the subject of construction and architecture, Kaunas University of Technology, Institute of Architecture and Construction. Kaunas: Technologija, 1996, p. 140-145 (in Lithuanian).

20. Aniskevich A. Moisture sorption in aramid composite on different structural and physical levels. In: Proc. of tenth int. conf. on composite Materials (ICCM-10), Whistler, British Columbia, Canada, Aug 14-18, 1995, Vol IV: Characterization and ceramic matrix composites. Abington: Woodhead Publ. Ltd, 1995, p. 367-374.

21. Carmeliet J. and Roels S. Description of the moisture capacity of building materials In: Proc. of $6^{\text {th }}$ symposium on building physics in the Nordic countries, Trondheim, Norway, 2002, p. $485-492$.

22. Hansen K. K. Equipment for and results of water vapour transmission tests using cup methods. In: Proc. of ICHMT symp. heat and mass transfer in building materials and structures, Dubrovnik, Yugoslavia, 1989, p. 267-271. 